\title{
Occupational asthma in a mineral analysis laboratory
}

\author{
A W MUSK, S PEACH, G RYAN \\ From the Department of Respiratory Medicine, Sir Charles Gairdner Hospital, Nedlands 6009, Western \\ Australia
}

ABSTRACT An epidemic of symptoms suggestive of occupational asthma in workers in a mineral analysis laboratory necessitating exposure to vapours of hydrochloric, hydrofluoric, nitric, perchloric, and sulphuric acid solutions was investigated. Variable airflow obstruction was confirmed by serial measurement of $\mathrm{FEV}_{1}$ in two subjects who showed $18 \%$ and $22 \%$ fall in $\mathrm{FEV}_{1}$ during a workshift. Of a workforce of 21 laboratory staff, 20 took part in a study of ventilatory capacity and bronchial reactivity. All but one subject had normal ventilatory capacity but five had bronchial hyperreactivity $\left(\mathrm{PC}_{20} \leqslant 8 \mathrm{mg} / \mathrm{ml}\right.$ histamine). Four of the five with hyperreactivity had a history of chest tightness at work whereas only two subjects with chest tightness had $P_{20}>8 \mathrm{mg} / \mathrm{ml}(\mathrm{p}<0.01)$. Other work related symptoms were cough (two subjects) and breathlessness (three subjects). Four of the subjects with bronchial hyperreactivity were atopic, suggesting that hyperreactivity may have predated exposure to irritant material at work and resulted in their being susceptible to the development of symptoms and raises the possibility of identifying susceptible subjects by preplacement examination. In two of these subjects, however, bronchial reactivity has returned to normal after 205 and 376 days away from work, suggesting that bronchial inflammation resulted from occupational exposure to acid vapours.

Seven workers in a laboratory which employed up to 21 technical and clerical staff to analyse mineral samples for the mining industry developed chest tightness and retrosternal discomfort, breathlessness or cough, or both, which started during the summer months at a time when the workload of the laboratory increased greatly. All related their symptoms to their work.

Rock samples from throughout Australia and elsewhere are received by the laboratory for analysis of their mineral content. They are crushed finely in a shed that houses crushing machinery and then transferred to a laboratory building where they are weighed in a weighing room and transferred to another room where quantitative analysis is undertaken. The minerals are dissolved in concentrated solutions of hydrochloric, hydrofluoric, nitric, perchloric, and sulphuric acids including "aqua regia", after which they are "digested" by heating them in open beakers in fume cupboards for $1-18$ hours. The resulting solutions are then submitted for atomic absorption (AA) and inductive coupled plasma (ICP) spectrometry in separate adjacent rooms in the laboratory building. Opportunities for exposure to vapours from concen-

Accepted 6 April 1987 trated acid solutions occurred in decanting the acids and transferring the beakers to and from the fume cupboards, from escape of vapours beneath the sashes of the fume cupboards during digestion, and from recirculation of the air exhausted from the fume cupboards into the laboratory building's air conditioning system at times when the wind blew exhausted air from the discharge vent over the roof of the building towards the intake vent.

This study was undertaken to investigate the prevalence of symptoms in the laboratory workforce, the relation of these symptoms to opportunities for exposure to acid vapours, and the occurrence of changes in lung function accompanying the symptoms. It was designed as a cross sectional survey to include all current employees and those who had recently resigned and also those absent from work because of respiratory symptoms. Four current employees also agreed to make serial measurements of

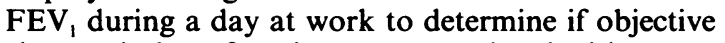
changes in lung function were associated with symptoms at work. Additionally, three of the subjects whose bronchial reactivity was found to be increased had serial measurements of reactivity while they continued at work and after they had left work.

By the time the study was conducted the volume of 
Table 1 Subject characteristics

\begin{tabular}{|c|c|c|c|c|c|}
\hline Subject & Age & Work areas & Smoking & $\begin{array}{l}\text { Chronic } \\
\text { bronchitis }\end{array}$ & $\begin{array}{l}\text { Work related } \\
\text { symptoms }\end{array}$ \\
\hline \multicolumn{6}{|c|}{ Men } \\
\hline 1 & 37 & Admin/lab & $\mathbf{N}$ & + & $\mathbf{T}$ \\
\hline 2 & 27 & Lab & $\mathbf{N}$ & - & $\mathbf{T}$ \\
\hline 3 & 28 & $\mathrm{Lab}$ & $\mathrm{E}$ & - & - \\
\hline 4 & 48 & Sample prep & $\mathrm{C}$ & + & - \\
\hline 5 & 23 & Sample prep & $\mathbf{E}$ & + & $\mathrm{C}$ \\
\hline 6 & 25 & Sample prep & $\mathrm{C}$ & - & - \\
\hline 7 & 31 & $\mathrm{Lab}$ & $\mathrm{C}$ & - & - \\
\hline 8 & 36 & Lab & $\mathbf{E}$ & - & - \\
\hline 9 & 58 & Office & $\overline{\mathbf{C}}$ & + & - \\
\hline \multicolumn{6}{|c|}{ Women } \\
\hline 10 & 29 & Lab & $\mathrm{C}$ & - & DT \\
\hline 11 & 31 & AA lab & $\mathbf{N}$ & - & DT \\
\hline 12 & 38 & AA lab & $\mathbf{N}$ & + & DTC \\
\hline 13 & 24 & AA lab & C & - & $\mathrm{T}$ \\
\hline 14 & 23 & Reception & $\mathbf{N}$ & - & - \\
\hline 15 & 27 & $\mathrm{Lab}$ & C & - & - \\
\hline 16 & 34 & $\mathrm{Lab}$ & C & - & - \\
\hline 17 & 27 & $\mathrm{Lab}$ & $\mathbf{N}$ & - & - \\
\hline 18 & 43 & Wash room & $\mathrm{E}$ & - & - \\
\hline 19 & 20 & $\mathrm{Lab}$ & $\mathbf{N}$ & + & - \\
\hline 20 & 24 & Lab & $\mathrm{C}$ & - & - \\
\hline
\end{tabular}

C, current; E, ex; N, never; C, cough; D, dyspnoea; T, chest tightness; R, rhinitis; A, asthma; B, bronchitis.

work in the laboratory had declined and an additional air conditioning unit had been installed.

\section{Subjects}

The 21 people employed when symptoms started in the index case were invited to take part in the study. Subject 2 who had subsequently resigned for nonmedical reasons attended but one subject who had been away from work for three months because of a non-respiratory illness declined to take part. Subjects 10,11 , and 12 who were on sick leave because of respiratory symptoms at the time of the study were included. There were nine men and 11 women aged 2058 (mean age 31.6 years, SD 9.5 years) (table 1). Subjects 4,5 , and 6 worked only in the rock crushing shed where they had no exposure to fumes from the laboratory building. Subject 14 worked as a receptionist in the same building as the main laboratory and subject 9, a supervisor, worked from his own office in the same building. The other 15 subjects worked at least half of their time in the main laboratory. Subjects 11,12 , and 13 also worked in the room housing the atomic absorption spectrometer.

Four subjects (numbers 9, 11, 12, and 13) agreed to make serial measurements of FEV $_{1}$ during a day at work. Subjects 10,11 , and 12 who had bronchial hyperreactivity were followed up with repeated measurements over periods of up to 15 months to determine if change occurred after removal from exposure.

\section{Methods}

QUESTIONNAIRE

All subjects answered a standard questionnaire on respiratory symptoms, smoking habit, and occupational history based on the British Medical Research Council (1976) questionnaire with additional questions on the presence of rhinitis ("an itchy running nose") and the relation of cough, breathlessness, and chest tightness to work. A history of "asthma," rhinitis ("hay fever"), and "bronchitis" was sought. "Chronic bronchitis" was taken as cough or phlegm on most days for as much as three months each year. Subjects were asked "Do you think that work at the laboratory has affected your chest?"

\section{PULMONARY FUNCTION}

Forced expiratory volume in one second $\left(\mathrm{FEV}_{1}\right)$ and forced vital capacity (FVC) were measured using a dry wedge spirometer (Vitalograph, Buckingham, UK). After as many practice attempts as were required to achieve satisfactory technique, three forced expiratory spirograms were recorded and accepted as satisfactory if the FVC was within 5\% of the best FVC.' Results were corrected to BTPS. The highest measurements of $F_{1} V_{1}$ and $F V C$ from the three manoeuvres were taken for analysis. Predicted FEV, and FVC were obtained from Knudson et $a .^{2}$

Non-specific bronchial reactivity to histamine was measured during tidal breathing with continuous aerosol delivery. ${ }^{3}$ Subjects inhaled physiological saline 


\begin{tabular}{|c|c|c|c|c|c|c|}
\hline $\begin{array}{l}\text { Current } \\
\text { Chinitis }\end{array}$ & $\begin{array}{l}\text { Past } \\
\text { illness }\end{array}$ & $\begin{array}{l}\text { Work affected } \\
\text { chest }\end{array}$ & $\begin{array}{l}\text { Skin tests } \\
\text { positive }\end{array}$ & $\begin{array}{l}\text { FEV } \\
\text { (\% pred) }\end{array}$ & $\begin{array}{l}\text { FVC } \\
\text { (\% pred) }\end{array}$ & $\begin{array}{l}P C_{20} \\
(m g / m l)\end{array}$ \\
\hline \multicolumn{7}{|c|}{ Men } \\
\hline - & $\mathbf{R}$ & + & 4 & 127 & 116 & $>8$ \\
\hline+ & RA & + & 4 & 109 & 116 & $2 \cdot 2$ \\
\hline- & $\mathbf{R}$ & - & 1 & 97 & 106 & $>8$ \\
\hline+ & $\mathbf{R}$ & - & 1 & 106 & 94 & $>8$ \\
\hline+ & - & + & 0 & 118 & 113 & $>8$ \\
\hline- & - & - & 2 & 111 & 107 & $>8$ \\
\hline - & - & - & 0 & 104 & 99 & $>8$ \\
\hline+ & B & - & 0 & 119 & 126 & $>8$ \\
\hline- & $\bar{B}$ & - & 1 & 34 & 88 & 0.04 \\
\hline \multicolumn{7}{|c|}{ Women } \\
\hline - & - & + & 0 & 103 & 105 & 0.3 \\
\hline - & - & + & 6 & 84 & 108 & $2 \cdot 1$ \\
\hline- & - & + & 1 & 113 & 111 & $8 \cdot 0$ \\
\hline+ & RAB & + & 3 & 98 & 94 & $>8$ \\
\hline+ & - & - & 0 & 84 & 77 & $>8$ \\
\hline- & - & + & 0 & 86 & 92 & $>8$ \\
\hline+ & - & - & 0 & 119 & 114 & $>8$ \\
\hline+ & - & - & 4 & 107 & 116 & $>8$ \\
\hline- & - & - & 0 & 102 & 91 & $>8$ \\
\hline+ & B & + & 0 & 122 & 114 & $>8$ \\
\hline- & B & - & 0 & 105 & 96 & $>8$ \\
\hline
\end{tabular}

and then doubling concentrations of histamine starting at $0.06 \mathrm{mg} / \mathrm{ml}$ until $\mathrm{FEV}_{1}$ fell by $20 \%$ from the postsaline level or a concentration of $8 \mathrm{mg} / \mathrm{ml}$ was reached. The concentration of histamine resulting in a $20 \%$ fall in $\mathrm{FEV}_{1}\left(\mathrm{PC}_{20}\right)$ was obtained by linear interpolation of the last two points of the dose response curve. Bronchial hyperreactivity was defined as a $P_{20} \leqslant 8 \mathrm{mg} / \mathrm{ml}$.

\section{ATOPIC STATUS}

Prick skin tests to various common allergens (grass pollens, house dust mite, cat and dog danders, and Aspergillus sp (Hollister Stier, Spokane, USA) were administered. ${ }^{4} \mathrm{~A}$ weal of $\geqslant 3 \mathrm{~mm}$ and greater than the negative control was taken as positive. Subjects were considered to be atopic if at least one skin test response was positive. ${ }^{\mathrm{s}}$

\section{Results}

\section{INDEX CASE}

Subject 10, a 29 year old female laboratory supervisor, was referred for assessment of respiratory symptoms which she related to her work. She had smoked 10-15 cigarettes a day since the age of 21 and had a recent history of investigation for amenorrhoea but no other relevant history. Her sister had died from cystic fibrosis. She had worked in similar laboratories since the age of 17. Six months earlier she had noticed breathlessness, cough, and retrosternal discomfort starting during the day at work and persisting at night.
These symptoms improved at weekends but progressively became more severe over a period of three months while she remained at work. They improved when she was moved to work out of the main laboratory and recurred when she returned, improving again when she left work. Pulmonary function assessment showed normal lung volumes, ventilatory capacity, and gas transfer but severe bronchial hyperreactivity that persisted until just over 12 months after leaving work when it was found to be normal (table 2).

\section{WOR KFORCE STUDY}

Nine subjects (eight of whom were laboratory workers) thought that work had affected their chests (table 1). These included all subjects with work related cough, dyspnoea, or chest tightness and four of the five subjects with $P_{20} \leqslant 8 \mathrm{mg} / \mathrm{ml}$. The fifth subject with $\mathrm{PC}_{20} \leqslant 8 \mathrm{mg} / \mathrm{ml}$ was the subject with chronic airflow obstruction (subject 9) who attributed his chest condition to cigarettes.

All the subjects who complained of dyspnoea or chest tightness at work had worked in the laboratory area (main laboratory or atomic absorption room). The one subject who had work related symptoms and worked outside the main laboratory in the rock crushing shed complained only of cough. Ten subjects were atopic including the man with chronic airflow obstruction and four of the five subjects with $\mathrm{PC}_{20} \leqslant 8$ $\mathrm{mg} / \mathrm{ml}$. The association between atopy and bronchial reactivity, however, was not statistically significant in this small group. Nor was there an association 
Table 2 Serial measurements of bronchial reactivity

\begin{tabular}{|c|c|c|c|}
\hline & Date & Days since worked & $P C_{20}$ \\
\hline Subject 10 & $\begin{array}{r}\text { 20. } 6.85 \\
\text { 26. } 7.85 \\
\text { 31. } 7.85 \\
5.11 .85 \\
\text { 20. } 5.86 \\
\text { 12. } 8.86\end{array}$ & $\begin{array}{l}\left.\begin{array}{l}42 \\
78 \\
83 \\
96\end{array}\right\} \\
\text { (Returned to work } 1.8 .85 \text { for } 4 \text { days) } \\
292 \\
376\end{array}$ & $\begin{array}{l}0 \cdot 26 \\
\text { Unable to do: persistent cough with saline inhalation } \\
0 \cdot 72 \\
0.84 \\
>8\end{array}$ \\
\hline Subject 11 & $\begin{array}{r}\text { 21. } 6.85 \\
\text { 19. } 7.85 \\
6.8 .85 \\
\text { 17. } 9.85 \\
5.11 .86\end{array}$ & $\begin{array}{l}10 \\
37 \\
55 \\
37 \\
\text { (Returned to work } 7.8 .85 \text { for } 4 \text { days) } \\
451\end{array}$ & $\begin{array}{l}2 \cdot 15 \\
2 \cdot 32 \\
2 \cdot 39 \\
3 \cdot 31 \\
3 \cdot 47\end{array}$ \\
\hline Subject 12 & $\begin{array}{r}\text { 4. } 7.85 \\
\text { 30. } 7.85 \\
6.9 .85 \\
28.10 .85 \\
\\
\text { 13. } 12.85 \\
17.1 .86 \\
21.5 .86 \\
4.8 .86\end{array}$ & $\begin{array}{l}24 \\
51 \\
0 \\
\text { (Worked } 37 \text { days on ICP machine) } \\
0 \\
\text { (Worked } 89 \text { days on ICP machine) } \\
5 \\
40 \\
128 \\
203\end{array}$ & $\begin{aligned}>8 \\
>8 \\
>8 \\
\\
6.69 \\
\\
5.06 \\
5.56 \\
4.70 \\
>8\end{aligned}$ \\
\hline
\end{tabular}

between bronchial reactivity and rhinitis.

Six subjects in the study gave symptoms of "chronic bronchitis" including the oldest, the 58 year old male smoker with known chronic airflow obstruction (subject 9) and two of the crushing plant workers, one a current smoker and the other an ex-smoker. The presence of chronic bronchitis was not significantly associated with smoking status or work related symptoms in this small group. All participants apart from subject 9 had FEV 1 greater than $83 \%$ of the predicted level (mean 106\%, SD 12\%).

Five subjects gave a history of hay fever and all were atopic. There was, however, no significant statistical association between the presence of current rhinitis on the one hand and atopy or other respiratory symptoms on the other. In particular there was no relationship of current rhinitis with work related lower respiratory symptoms.

Two subjects, one of whom worked in the rock crushing area, considered that activity at work resulted in cough. Three complained of breathlessness at work and six thought that work was associated with chest tightness. All subjects who complained of breathlessness or chest tightness worked in the main laboratory and four of them had $\mathrm{PC}_{20} \leqslant 8 \mathrm{mg} / \mathrm{ml}$ ( $\mathrm{p}<$ $0 \cdot 01$ ).

Serology for respiratory viruses (adenovirus, influenza $A$ and $B$, parainfluenza 1, 2, and 3, respiratory syncitial virus, $Q$ fever, coronavirus, psittacosis, Lymphogranuloma venereum, Mycoplasma pneumoniae) was performed in all subjects with respiratory symptoms. No evidence of recent infection was found.

WORKSHIFT CHANGES IN FEV

Serial measurements of FEV , starting from the time they arrived at work were made in subjects $9,11,12$, and 13 (figure) who remained in employment at the laboratory. Three of these (subjects 11,12, and 13) had complained of work related breathlessness or chest tightness or both, and subject 9 was a cigarette smoker with chronic bronchitis and chronic airflow obstruction who used a salbutamol metered dose inhaler at irregular intervals for the relief of breathlessness. A $22 \%$ fall was recorded in subject 11 while she was using the atomic absorption spectrometer and was associated with the sensation of retrosternal discomfort and chest tightness. Subject 12 who had no symptoms at the time of the test recorded an $18 \%$ fall in $\mathrm{FEV}_{1}$. No consistent change in $\mathrm{FEV}_{1}$ or symptoms were recorded by the other two workers.

\section{SERIAL CHANGES IN BRONCHIAL REACTIVITY}

Repeated measurements of bronchial reactivity were made in subjects 10,11 , and 12 who were the most symptomatic workers (table 2). No significant change was observed despite removal from further exposure to irritant materials for between two and nine months. After seven and 12 months, however, subjects 12 and 10 had regained normal reactivity. Reactivity in subject 11 was unchanged after 15 months from last exposure, although she had no chest tightness, breathlessness, wheeze, or cough when seen in November 1986. 


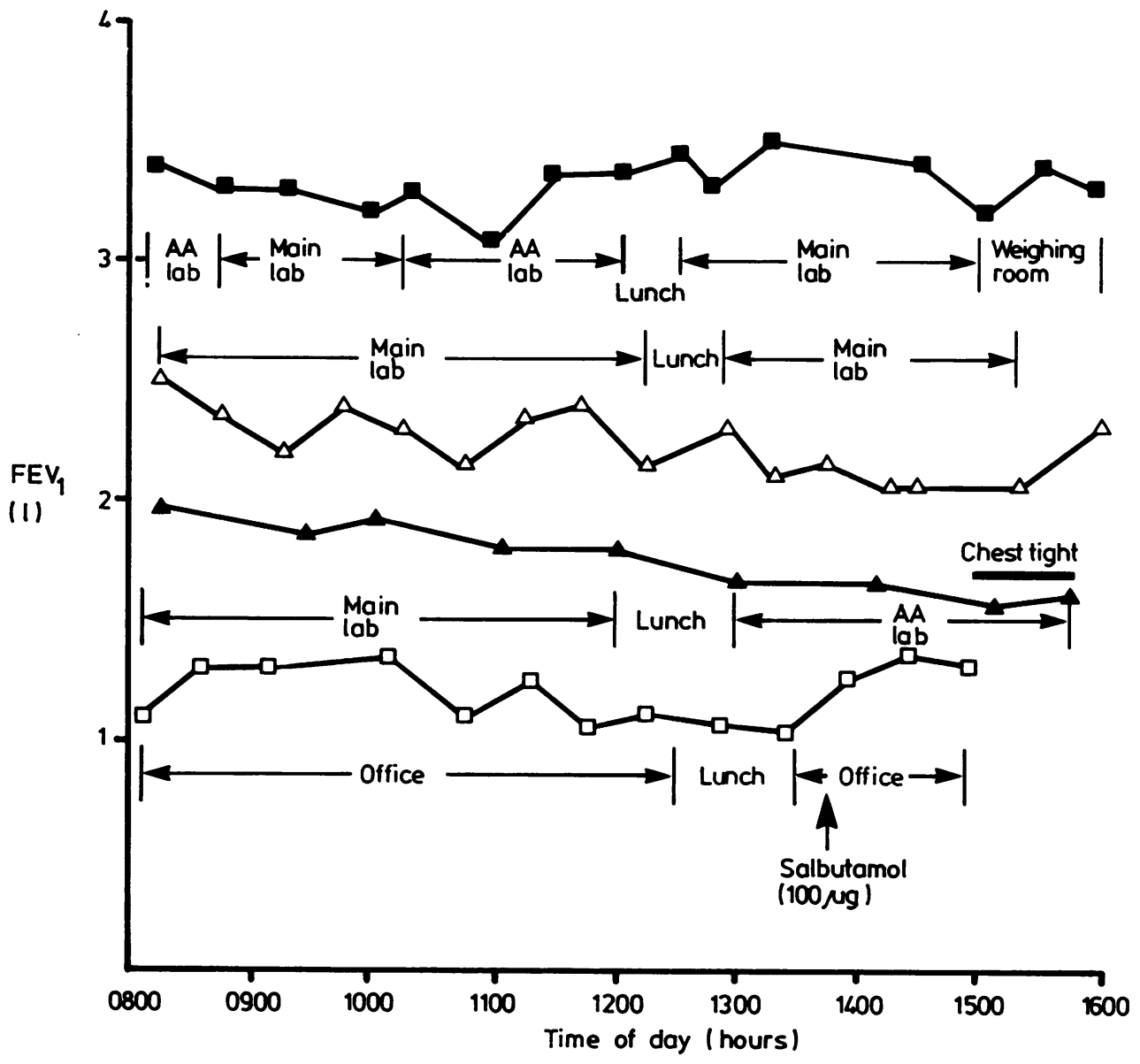

Serial measurements of FEV, during workday in four subjects (top to bottom subjects 13, 12, 11, and 9). Workplace areas are indicated.

\section{Discussion}

The symptoms of work related breathlessness and chest tightness experienced by some of the subjects in this study appear to reflect asthma, which was shown in subject 11 whose $\mathrm{FEV}_{1}$ fell by $22 \%$ during a workshift and which was probably present in subject 12 whose FEV fell by $18 \%$ during a workshift. Four of the six subjects with chest tightness or dyspnoea or both, at work also had bronchial hyperreactivity to histamine consistent with the presence of asthma. Inferences on the aetiology of this asthma are limited by the small number of exposed subjects. The results are consistent with aggravation of pre-existing subclinical asthma (asymptomatic bronchial hyperreactivity) by exposure to irritant fumes at work or the induction of bronchial hyperreactivity and symptoms by the acid fumes.

The hypothesis of aggravation of pre-existing subclinical asthma by irritant workplace exposure to acid fumes is consistent with the failure of hyperreactivity to subside after removal of the subjects from exposure for periods up to 15 months. ${ }^{6}$ Bronchial hyperreactivity induced by viral infections, ${ }^{78}$ exposure to cigarette smoke, ${ }^{9} \mathrm{NO}_{2},{ }^{10} \mathrm{SO}_{2},{ }^{11}$ or ozone ${ }^{12}$ improves when the offending agent is removed. The rate of return to normal reactivity may be slow and incomplete, especially with allergen induced occupational asthma resulting from agents such as Western red cedar, colophony, isocyanates, and crab." All but one of the five subjects with bronchial hyperreactivity in this study were also atopic, which is consistent with 
other observations of an association between bronchial reactivity and atopic status, ${ }^{13}$ although this association was not statistically significant in this small group and there was no association of bronchial reactivity with rhinitis. The implication of this finding would be that preplacement testing of subjects for the presence of hyperreactive airways may identify those who are susceptible to exposure.

The alternative explanation for the findings of this study is that bronchial hyperreactivity in these subjects resulted from repeated exposure to irritant acid fumes which caused bronchial inflammation and hyperreactivity. ${ }^{74} \mathrm{~A}$ precedent for this is found with exposure of man or animals to ozone or chlorine..$^{14}$ is One previous observation has drawn attention to persistent hyperreactivity in subjects exposed acutely to unusually high levels of an irritating aerosol in whom symptoms developed within a few hours and continued for periods of four years or more and in whom bronchial wall biopsy showed inflammation. ${ }^{6}$ Consistent with this hypothesis is the fact that in two of the three subjects with hyperreactivity who underwent serial testing in this study, recovery to normal levels of reactivity has been observed after seven and 12 months. Verification of this possibility would require a longitudinal study with measurements of bronchial reactivity starting before hiring.

Inhalation of substantial quantities of hydrochloric or other soluble gas results in acute inflammation of airways at all levels which may be fatal. ${ }^{16}$ Ozone is also an irritant that is known to cause reversible airway narrowing in concentrations of $0.4-0.5 \mathrm{ppm},{ }^{14}$ although adaptation to these effects has been recorded. ${ }^{15}$ In appropriate (lower) concentrations both $\mathrm{SO}_{2}$ and ozone may cause bronchial hyperreactivity without interval airflow obstruction. ${ }^{1718}$ The levels of exposure to acid fumes experienced by the workers in this study were not documented. By the time they came to medical attention the volume of work in the laboratory had declined considerably, improvements had been made to the extraction of vapours from the fume cupboards, and alterations had been made to the air conditioning system of the laboratory. Further observations in this and similar laboratories will be required to answer scientific and practical questions concerning safe levels of exposure to acid vapours and whether non-specific bronchial reactivity is a determinant of symptoms or consequence of exposure.

The help of the company medical officer and the staff of the laboratory and Dr Fred Heyworth (previously Principal Medical Officer, Western Australian Department of Occupational Health, Safety and Welfare) is gratefully acknowledged. The audiovisual aids depart- ment of the Sir Charles Gairdner Hospital prepared the illustrations and Miss $\mathrm{E}$ Bingle provided secretarial help.

\section{References}

1 American Thoracic Society Statement. Snowbird workshop on standardisation of spirometry. Am Rev Respir Dis 1979;119:831-8.

2 Knudson RJ, Slavin RC, Lebowitz MD, Burrows B. The maximum expiratory flow-volume curve: normal standards, variability and the effects of age. Am Rev Respir Dis 1976;113:587-600.

3 Cockcroft DW, Killian DN, Mellon JJA, Hargreave FE. Bronchial reactivity to inhaled histamine: a method and clinical survey. Clin Allergy 1977;7:235-43.

4 Pepys J. Skin tests in diagnosis. In: Gell PGH, Coombs RRA, Lachman PJ, eds. Clinical aspects of immunology. 3rd ed. Oxford: Blackwell Scientific Publications, 1975:55-80.

5 Woolcock AJ, Coleman MH, Jones MW. Atopy and bronchial reactivity in Australian and Melanesian populations. Clin Allergy 1978;8:155-64.

6 Brooks SM, Weiss MA, Bernstein IL. Reactive airways dysfunction syndrome: case reports of persistent airways hyperreactivity following high-level irritant exposures. $J$ Occup Med 1985;27:473-6.

7 Empey DW, Laitinen LA, Jacobs L, Gold WM, Nadel JA. Mechanisms of bronchial hyperreactivity in normal subjects after upper respiratory tract infection. Am Rev Respir Dis 1976;113:131-9.

8 Dixon M, Jackson DM, Richards IM. The effect of a respiratory tract infection on histamine induced changes in lung mechanics and irritant receptor discharge in dogs. Am Rev Respir Dis 1979;120:843-8.

9 Boucher RC, Johnson J, Inone S, Hulbert W, Hogg JC. Effect of cigarette smoke on the permeability of guinea pig airways. Lab Invest 1980;43:90-100.

10 Orehek J, Massari JP, Gayrard P, Grimand C, Charpin J. Effect of short term low level nitrogen dioxide exposure on bronchial sensitivity of asthmatic patients. J Clin Invest 1976;57:301-7.

11 Hudson P, Cartier A, Pineau L, et al. Follow-up of occupational asthma caused by crab and various agents. J Allergy Clin Immunol 1985;76:682-8.

12 Golden JA, Nadel JA, Boushey HA. Bronchial hyperirritability in healthy subjects after exposure to ozone. Am Rev Respir Dis 1978;118:287-94.

13 Cookson WOCM, Ryan G, MacDonald S, Musk AW. Atopy, non-allergic bronchial reactivity and past history as determinants of work-related symptoms in seasonal grain handlers. $\mathrm{Br} J$ Ind Med 1986;43:396-400.

14 Seltzer J, Bigby B, Stulbarg M, et al. Ozone-induced change in bronchial reactivity to methacholine and airway inflammation in human subjects. J Appl Physiol 1986;60:1321-6.

15 Ferris BG, Puleo S, Chen HY. Mortality and morbidity in a pulp and paper mill in the United States: a ten year follow-up. $B r J$ Ind Med 1979;36:127-34.

16 Parkes WR. Occupational lung disorders. 2nd ed. London: Butterworths, 1982.

17 Fabbri L, Mapp C, Rossi A, Sarto F, Trevisan A, De Rosa E. Pulmonary changes due to low level occupational exposure to ozone. Med Lav 1979;4:307-12.

18 Farrell BP, Kerr HD, Kulle TJ, Sander LR, Young JL. Adaptation of human subjects to the effects of inhaled ozone after repeated exposure. Am Rev Respir Dis 1979;119:725-30. 